\title{
Identifying the groundwater basin boundaries, using environmental isotopes: a case study
}

\author{
Muhterem Demiroğlu'
}

Received: 17 October 2013/Accepted: 7 December 2016/Published online: 28 December 2016

(C) The Author(s) 2016. This article is published with open access at Springerlink.com

\begin{abstract}
Groundwater, which is renewable under current climatic conditions separately from other natural sources, in fact is a finite resource in terms of quality and fossil groundwater. Researchers have long emphasized the necessity of exploiting, operating, conserving and managing groundwater in an efficient and sustainable manner with an integrated water management approach. The management of groundwater needs reliable information about changes on groundwater quantity and quality. Environmental isotopes are the most important tools to provide this support. No matter which method we use to calculate the groundwater budget and flow equations, we need to determine boundary conditions or the physical boundaries of the domain. The Groundwater divide line or basin boundaries that separate the two adjacent basin recharge areas from each other must be drawn correctly to be successful in defining complex groundwater basin boundary conditions. Environmental isotope data, as well as other methods provide support for determining recharge areas of the aquifers, especially for karst aquifers, residence time and interconnections between aquifer systems. This study demonstrates the use of environmental isotope data to interpret and correct groundwater basin boundaries giving as an example the Yeniç1krı basin within the main Sakarya basin.
\end{abstract}

Keywords Groundwater basin · Groundwater divide line . Recharge area $\cdot$ Isotope

Muhterem Demiroğlu

demiroglum@itu.edu.tr

1 Geological Engineering Department, ITU Faculty of Mine, Maslak, Turkey

\section{Introduction}

Groundwater management is under pressure on increased water demand, climate change and pollution problems. The main scientific concern is the correct understanding of the changes in quality and quantity of groundwater caused by human activities and climate change. Decision makers needs modelling studies to understand and provide sustainable management. The success of modelling depends on reliable information on groundwater main parameters. Environmental isotopes are the most important tools to provide this support (Aggarwal et al. 2009; Surinaidu et al. 2014). Stable and unstable environmental isotopes have been used to study hydrological systems and have been proven particularly useful for understanding karst systems. Among the most important areas where isotopes are useful in groundwater applications include studies of recharge and discharge process, flow and interconnections between aquifers, and sources and mechanism of pollution. Radioactive decay of environmental isotopes makes these isotopes a unique tool for the determination of groundwater residence time (Mazor 1991; Aggarwal et al. 2009).

Groundwater models; It is the creation of a simplified form of the real groundwater system and the determination of the reactions of the system to the effects by being affected in a systematically controlled manner. These models (analytic or numerical) may only be functional if the process is conducted at the last part of the study and depends upon the competence of the modeller rather than the model itself (Voss 2011). That technique is advantageous since it facilitates representing the aquifers by dynamic models and enables authorities to assess the process through data acquisition and updating the data, planning, adjustment, comparison and interpretation. There are a wide range of models at present. The program 
MODFLOW can be run by a GIS processor and has been developed for both steady and unsteady flows and evaluation of the boundary conditions. Conceptual models yielded by those programs may be converted into appropriate mathematical models. One of the most important problems during the creation of a groundwater flow model representing a hydrogeological setting is to produce a very real-like conceptual model. How realistic and real-like the conceptual model is determined by usage of the accurate and detailed input data, only then the output is realistic to the same degree. Herein, the conceptual model term means spatial and extensional characteristics, in other words 3-D physical boundaries of the aquifers. Conceptualization is, perhaps, the most critical and the most important, in developing a groundwater model (Kresic 1997) and the design of a conceptual model is the subject of this article. Preparation of conceptual model requires identifying the study area, compiling detailed information on the geological formations, groundwater flow directions, recharge, hydraulic parameters and sinks or sources, and deciding appropriate boundary conditions. A basic way to evaluate the occurrence and movement of groundwater is defining basin or sub basin boundaries accounting for surface and groundwater system's inflows (recharge) and outflows (discharge). A groundwater reservoir is defined by an overlaying river drainage area and the underlying aquifers that contain the stored groundwater. Surface water divide lines identified by the highest elevations between two areas on a map separate river basins from each other. Basin boundaries may vary from small ridges to continentalscale.

A groundwater divide line usually coincides with a surface waters divide line, and that divide line also usually matches up with a surface water draining line in granular and unconfined aquifers (Fig. 1), while recharge areas of the karstic and confined aquifers mostly do not coincide with surficial drainage areas (White 2002; Gunn 2007; Palmer 2010). Karst systems are often characterized by substantial groundwater-surface water connections via processes such as aquifer recharge by losing streams, fracture and conduit connections between surface water and groundwater, and spring flow contributions to surface water (e.g., Katz et al. 1997; Musgrove et al. 2010).

As can be seen in Fig. 2, it is not easy for defining the basins which have complex hydrogeological properties. Specifying the groundwater divide line accurately and defining a grid system to which the boundary conditions and numerical simulations are based, and forms the basis of a modelling practice (Ünlü et al. 2004). Yeniçıkrı basin, located in the upper Sakarya basin in central Turkey is one of the examples representing that case (Fig. 2). Highyielding wells opened by the State Hydraulic Works in the small river basin, Yeniçıkri River, and Yeniçıkrı spring meet the drinking and irrigation water needs of the Kayakent township. Prepared water budget calculations using basin boundaries did not match with this rich aquifer. Shortly after the wells in the marbles were put into operation, Yeniç1krı spring ( $47 \mathrm{l} / \mathrm{s})$ dried up. Environmental isotope techniques were performed for determining the recharge area and residence time of groundwater for creating conceptual model.

\section{Study area and hydrogeology}

The units outcropping at Yeniçıkrı basin, from bottom to top, respectively, Paleozoic marble, which is the main reservoir rock for hot and cold water, are bordered by impermeable schists. Due to continually effective uprising and erosional processes, the marble outcroppings at the area are not so thick. Yet, depending on the low-dissolvability and being enclosed by impermeable zones such as granites and schists at the bottom, the marbles display no remarkable karstic formations at present. Characterized by the presence of welldeveloped karstic-reservoirs in Yeniçıkrı area, it has been interpreted that these structures were included in hydrological cycle as a result of step faults. Thereafter, the evaporiticlacustrian and tectonically active period terminated and all the units in the region, both the Miocene-aged and the older ones, have undergone erosional processes. Karstification in the carbonates began to develop in that time span. Emplacement of the Sakarya River is the primary factor controlling the energy gradient in the area (Ekmekçi 2003).

Marble, at the top of the metamorphic series, at higher elevations of the region, represents the upper part of the aquifer system and the lower part of the aquifer system as a result of step faults. Yeniçıkrı spring recharges, circulates and discharges from marbles and wells cut only in marbles. The marbles are overlain by the young units unconformably. They contain terrestrial detritics, light-colored and include laterally and vertically gradational silts, clays, gypsum, marls and mudstones (Fig. 3). The Neogene units are classified as very poor aquifer. According to the flow measurements made between 1986 and 2005, the average flow rate of Yeniç1krı spring is $47 \mathrm{lt} / \mathrm{s}$. The static level of wells is the same as the spring discharge elevation $(890$ meters). It can be said that Yeniçıkrı spring works like a spillover outlets. As a result of the operation of the wells, the water level has fallen and the spring has dried up. Pump tests in the marbles yielded hydraulic conductivities from 1.19 to $98.9 \mathrm{~m} /$ day and specific capacity ranges from 0.64 to $75 \mathrm{l} / \mathrm{s} / \mathrm{m}$ (Demiroglu et al. 2011).

As seen in Fig. 2, the drainage divide line at the Yeniçıkrı Basin passes through marbles displaying karstic characteristics, and for the determination of the recharge elevation environmental isotope techniques were 
Fig. 1 An unconfined aquifer boundary conditions (Fetter 2001)
Fig. 2 Schematic illustration the hydrogeological conceptual model of the Yeniçıkrı Basin
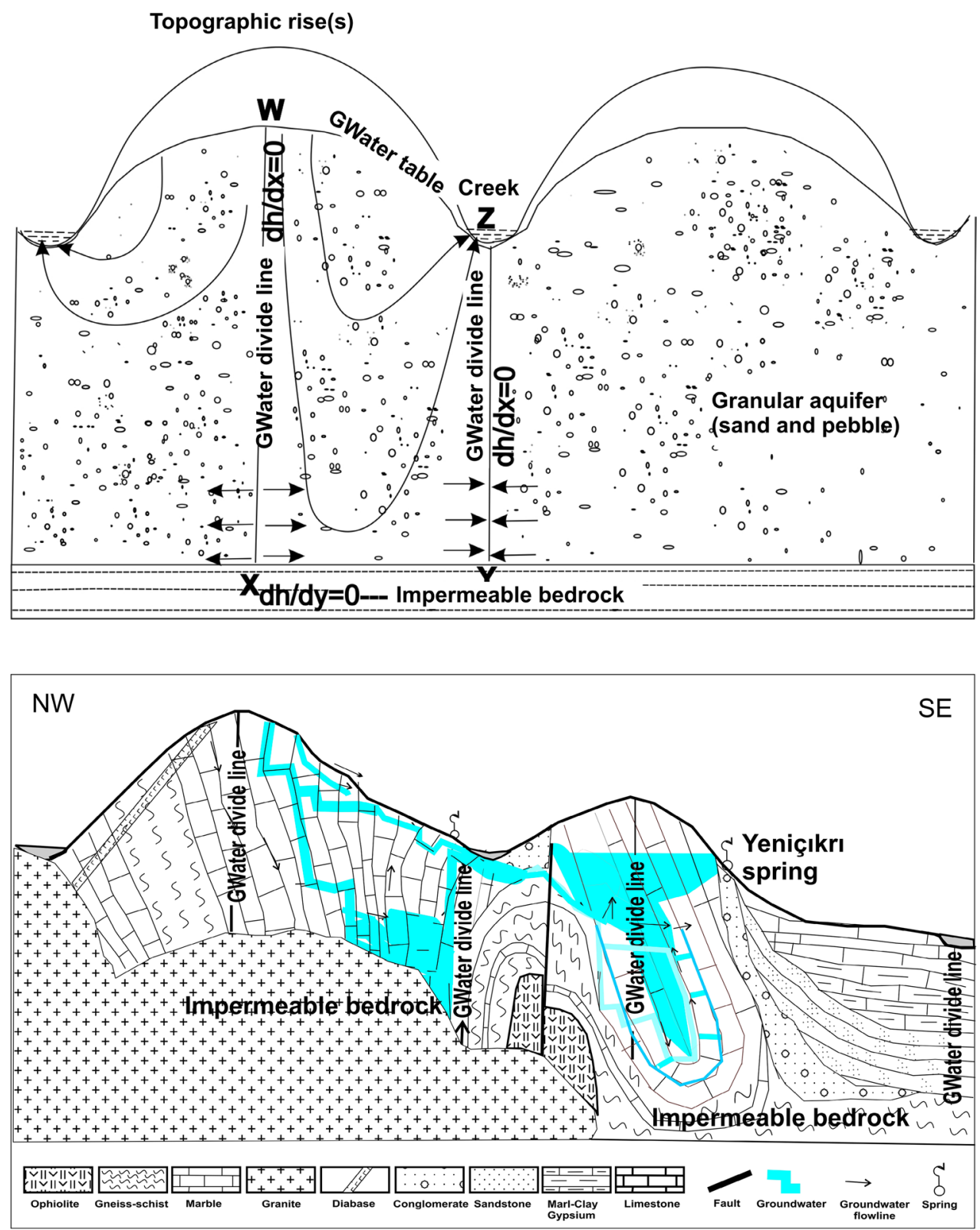

performed (Demiroglu 2008). Hydrogeological cross sections indicate the extent and continuity of lithologies (Fig. 3) and the discontinuities which can link the aquifer systems. Yeniçıkrı basin boundaries depend upon the extent of the lithologies were re-delineated and combined with Günyüzü basin after detailed hydrogeology, tectonics and isotope studies.

\section{Materials and methods}

The technique applied generally during these studies is to create a Digital Elevation Model (DEM) of the studied area and make an output model subject to the ArcMap
Hydrologic Modelling Extension (ESRI) application, and so to yield a map outlining basin water divide lines (Fig. 4). This boundaries didn't match with lithological groundwater boundaries and it is required to make some changes on borders using hydrogeological and hydrochemical data. Isotope techniques were applied in the determination of recharge areas more accurately.

Among the environmental isotopes participating in the hydrological cycle at different stages and included in the waters naturally, they occur naturally in water bodies and do not change during movement of groundwater. So these are used as tracers in both hydrology and hydrogeology (Tezcan 2002; Aggarwal et al. 2009). These isotopes can be measured by a specific type of mass spectrometer with 


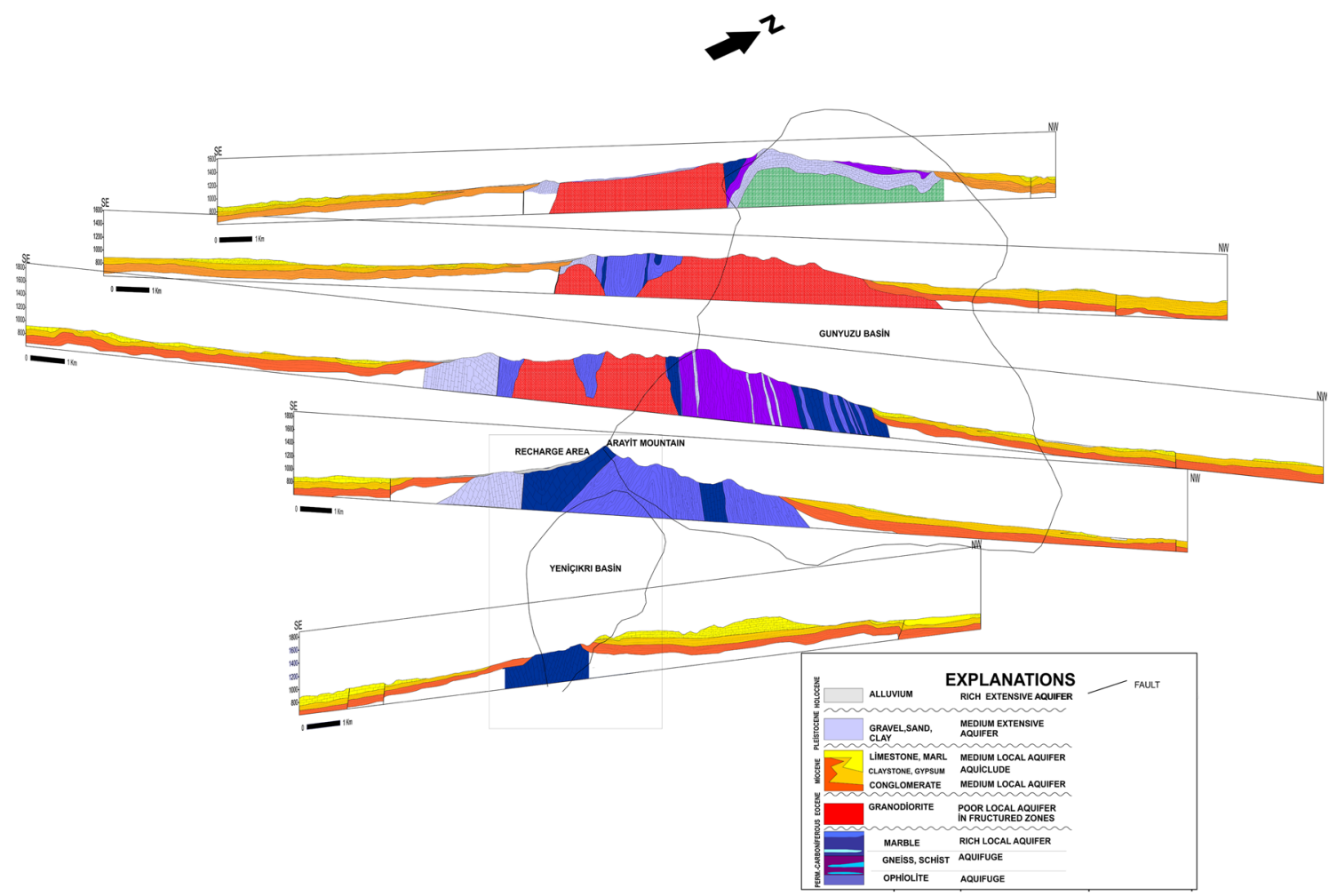

Fig. 3 Spatial cross section view of the study area

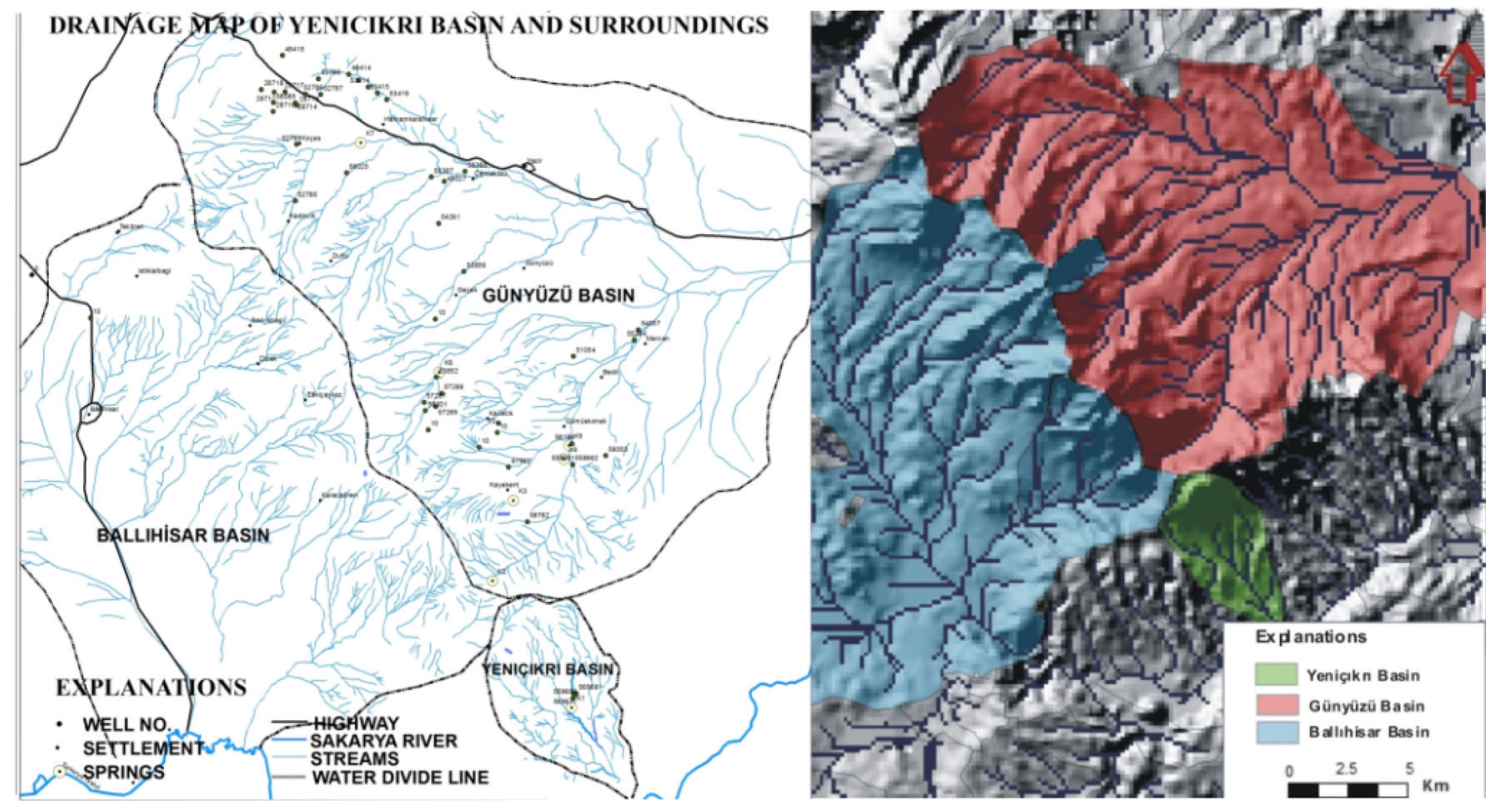

Fig. 4 a Drainage areas of Yeniçıkrı and surrounding basins (drawn by classical method). b Drainage areas representation drawn on Digital Elevation Model (DEM)

required sensibility equipment. Measured $\delta^{18} \mathrm{O}$ and $\delta^{2} \mathrm{H}$ figures do not reflect absolute concentrations, but just point out deviation (as per thousand) of isotopic rates from Standard Mean Ocean Water (SMOW).
Isotopic rates are expressed as $\delta$ notation as below:

$$
\delta_{(\%)}=\left[R_{\text {sample }}-R_{\text {standard }}\right] / R_{\text {standard }} \times 1000
$$


The $\delta$ is a relative value. In other words, the $\delta$ value reflects discrepancies of ${ }^{18} \mathrm{O} /{ }^{16} \mathrm{O}$ or $\mathrm{D} / \mathrm{H}$ ratios of the sample from ${ }^{18} \mathrm{O} /{ }^{16} \mathrm{O}$ or $\mathrm{D} / \mathrm{H}$ ratios of a standard. Through water analyses, accepted standard for isotopes is SMOW (Standard Mean Ocean Water) (Çifter and Sayın 2004; Aggarwal et al. 2009).

From previous works on isotope hydrology, it has been concluded that various factors such as geographic location, latitude, temperature, etc. affect heavy isotopes concentration of water vapor. It is a finding that, the $\delta^{18} \mathrm{O}$ content in atmospheric water vapor decreases toward continental and higher areas. Since temperature is one of the basic factors controlling evaporization, the concentration of heavy isotopes increases at higher temperature periods. Similarly, precipitations in the summer season have heavier isotopic composition than those of the winter season. Heavy isotope concentration of heavy rains is lower than those of showers. Heavy isotope content decreases gradually toward terrestrial areas in comparison with oceans and seas. Besides these parameters, heavy isotope concentration of the waters falls principally as the elevation increases; in other words, heavy isotopes concentration in the waters is in relation to altitude with an inversely proportional manner. Due to local climatic conditions, frontal precipitation system and the topography controlling the precipitation, the $\delta^{18} \mathrm{O}$ content of atmospheric water decrease ranges from -0.15 to $-0.5 \%$ per $100 \mathrm{~m}$ rise in altitude (Clark and Fritz 1997).

Springs discharging at different elevations and displaying seasonal variations in their flow rates (i.e., drying in summer period and yield increase in flow rates in rainy seasons) can also be made functional in establishing the relation between $\delta^{18} \mathrm{O}$ or $\delta^{2} \mathrm{H}$ and altitude when there has been no data representing precipitation and being gathered from different elevations. Göcenoluk, Akpınar, Gümüşbel and Musluk pinarı sample springs from different altitudes in nearby basins were used to represent precipitation for the Yeniçıkrı basin. Several factors may complicate the use of a mean annual $\delta^{18} \mathrm{O}$ value as an indicator of recharge elevations and may overestimate recharge elevations (Abbott et al. 2000). Groundwater flowing from the highest altitude of the spring's recharge area (lowest mean $d^{18} \mathrm{O}$ values) may become mixed with water recharged at lower elevations (higher mean $\delta^{18} \mathrm{O}$ values) along the flow path, as well as mixing with old water coming from deep circulation. Moreover, $\delta^{18} \mathrm{O}$ content of hot waters increases to some extent as a result of transfer between water and rock in higher temperature conditions. This interaction is evident at very high temperatures, $150{ }^{\circ} \mathrm{C}$ (Truesdell and Hulston 1980; Yildirim and Güner 2002). Using $\delta^{2} \mathrm{H}$-altitude relations are preferred to specify the altitude of recharge areas for geothermal springs since there is no variation in $\delta^{2} \mathrm{H}$ concentration of water in higher temperature water-rock interaction processes. Clark and Fritz (1997) has reported that the changing rate in $\delta^{2} \mathrm{H}$ isotope concentration varies between -1 to $-4 \%$ o per $100-\mathrm{m}$ rise in altitude.

Tritium $\left({ }^{3} \mathrm{H}\right)$, an unstable, a short-lived isotope of hydrogen with a half-life of 12.3 years, is a commonly used tracer for determining the age of groundwater less than fifty years old. Tritium concentrations are expressed in tritium units (TU), where one TU indicates that one of the $10^{18}$ hydrogen atoms is the Tritium $\left({ }^{3} \mathrm{H}\right)$ atom (Clark and Fritz 1997; Fetter 2001). Tritium is produced naturally in the stratosphere by the effects of cosmic radiation on ${ }^{14} \mathrm{~N}$, and enters the hydrologic cycle via precipitation. Large volumes of anthropogenic tritium were produced between 1951 and 1962 by atmospheric testing of thermonuclear weapons. Use of the tritium isotope for dating modern groundwater now relies upon the largely natural ${ }^{3} \mathrm{H}$ signal (Land and Huff 2009). Tritium concentrations in precipitation sample or seasonal, low circulated, small springs discharging at different elevations, can accept modern or current groundwater. A mean $12 \mathrm{TU}$ value in Yeniçıkrı basin are considered to be modern groundwater. Carbon-14 $\left({ }^{14} \mathrm{C}\right)$ is a commonly used tracer for determining the age of groundwater more than fifty years old. Carbon isotope is a naturally occurring radioactive isotope of carbon, and was also produced by atmospheric thermonuclear testing during the mid-twentieth century, similar to Tritium. The ${ }^{14} \mathrm{C}$ radioactivity of inorganic carbon in water is expressed in terms of Percent Modern Carbon (PMC) relative to the abundance of ${ }^{14} \mathrm{C}$ in atmospheric $\mathrm{CO}_{2}$. Once isolated from atmospheric gases, the abundance of ${ }^{14} \mathrm{C}$ decreases at a rate governed by its half-life of 5730 years (Land and Huff 2009).

\section{Results and discussions}

Göcenoluk, Akpınar, Gümüşbel and Musluk pınarı springs from different elevations in nearby basins were used to represent precipitation for the Yeniçırı basin and the $\delta^{18} \mathrm{O}$ changing rate for increasing elevation has been determined as $-0.32 \%$ per $100 \mathrm{~m}$ rise in altitude (Demiroglu 2008; Demiroglu et al. 2011).

Accordingly, the decrease in $\delta^{18} \mathrm{O}$ concentration for each $100 \mathrm{~m}$ increase in altitude is $-0.32 \%$. Data on the $\delta^{18} \mathrm{O}$ content in Yeniçıkrı spring gave rise to a conclusion that the altitude of the catchment area of that spring is about $1465 \mathrm{~m}$ (Fig. 4). It shows that the recharge areas of the Yeniçıkrı spring extend into Arayit Mountain, distant from the water divide line of the Yeniçıkr basin that this spring lies within (Fig. 5).

The mean $\delta^{2} \mathrm{H}$ values on the contrary point out an elevation reaching to $2276 \mathrm{~m}$ (Fig. 6). In this region the 


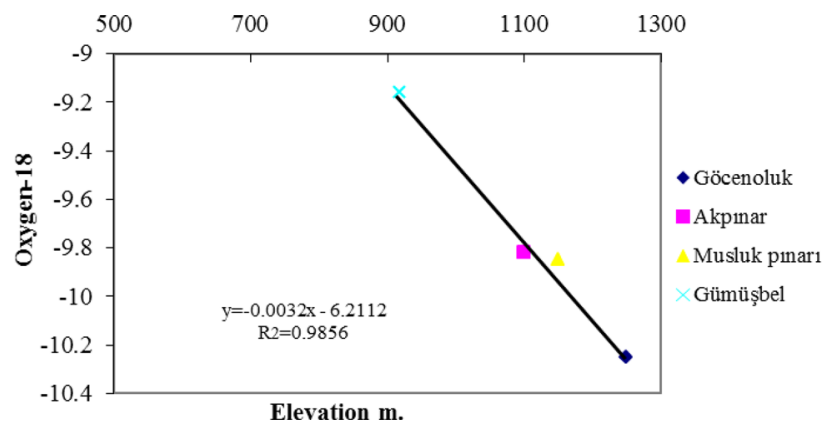

Fig. 5 The relationship between the Oxygen-18 $\left(\delta^{18} \mathrm{O}\right)$ and elevation

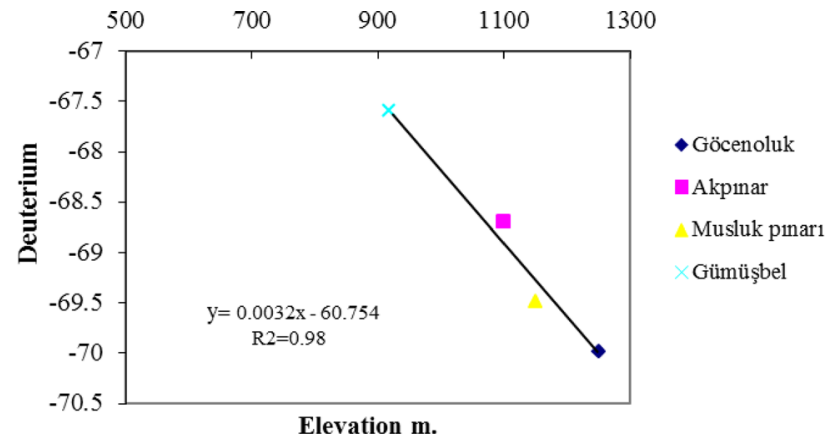

Fig. 6 The relationship between the Deuterium $\left(\delta^{2} \mathrm{H}\right)$ and elevation

present topography pictures indicates ridges reach up to only $1817 \mathrm{~m}$. In that respect data gained from isotopes points out that, the catchment area of the Yeniçıkrı basin extends into Arayit Mountain (1.817) and the presence of static water stored under quite different conditions than those actually prevailing. Tritium concentrations in the groundwater range from 12 to $2.3 \mathrm{TU}$, indicating that groundwater residence times may vary from less than 1 year to in excess of 30 years. But in reality the aquifer is a mixture of two different deep and shallow circulating waters. The age of the deep-circulated ground waters was determined to be 10,000 years by ${ }^{14} \mathrm{C}$ analysis in the Çardak hamamı spring which occurs in the same karstic system (Demiroglu and Örgün 2014).

Heavy isotopes were also used to specify the elevation of the catchment area of Sakarbaşı (Sivrihisar/Eskişehir) springs, discharging at lower altitudes and located within the boundaries of main Sakarya drainage area (Günay 2006). Reflecting a discharge of a $300 \mathrm{~m}$ height, Kırkgözeler (Antalya) spring group has a catchment area reaching to heights varying from 1918 to $2827 \mathrm{~m}$ (Atilla 1996). Günay and Bayarı (1989) has concluded that the decrease reaches up to $-0.25 \%$ for each $100 \mathrm{~m}$-height in Köprüçay Basin. Likewise, the decrease in the ${ }^{18} \mathrm{O}$ values between -0.15 and $-0.25 \%$ for the same change in elevation has been determined at the Gökova karstic springs area by Kurttaş (1997). These results make environmental isotopes unique tools for the determination of groundwater basin boundaries.

\section{Conclusions}

The measurement of environmental isotopes in addition to evaluate the lithological and structural features gave rise to a conclusion that catchment areas of the springs extend into regions well distant from water divide lines of the basins that these springs lie within.

In that context, one can say that, for specifying the catchment areas of the basins displaying complex boundary conditions due to complex geological structure as in the case of the Yeniçıkrı Basin, it is required to make functional the stable isotopes techniques.

Acknowledgements The manuscript has been edited in terms of its language by Darwin E. Fox, whom the authors deeply thank for the helpful comments improving the manuscript.

Open Access This article is distributed under the terms of the Creative Commons Attribution 4.0 International License (http:// creativecommons.org/licenses/by/4.0/), which permits unrestricted use, distribution, and reproduction in any medium, provided you give appropriate credit to the original author(s) and the source, provide a link to the Creative Commons license, and indicate if changes were made.

\section{References}

Abbott MD, Lini A, Bierm PR (2000) d18O, dD and 3H measurements constrain groundwater recharge patterns in an upland fractured bedrock aquifer, Vermont, USA. J Hydrol 228:101-112. doi:10.1016/S0022-1694(00)00149-9

Aggarwal PK, Froehlich K, Kulkarni KM (2009) Environmental isotopes in groundwater studies. Groundwater 2:69

Atilla AÖ (1996) Assessment of hydrogeochemical data using multivariate statistical analysis techniques. Hacettepe University, Institute of Science and Technology (unpublished), Master Thesis

Çifter C, Sayın M (2004) Use of isotopes in hydrology, 1. Symposium on the use of isotope techniques in national hydrology, Adana

Clark D, Fritz P (1997) Environmental Isotopes in hydrogeology. CRC Press LLC, USA, p 312

Demiroğlu M (2008) Hydrogeology and hydrogeochemistry of Eskişehir-Sivrihisar-Günyüzü basin. Doctorate Thesis, Istanbul Technical University, Institute of Science and Technology (unpublished)

Demiroglu M, Örgün Y (2014) Hydrogeochemical properties and age of the Çardak Hamamı spring. International 6th Geochemistry Symposium, Mersin, pp 201-202

Demiroglu M, Örgün Y, Yaltırak C (2011) Hydrogeology and hydrogeochemistry of Gunyuzu semi-arid basin. Environ Earth Sci 64:1433-1443

Ekmekçi M (2003) Review of Turkish karst with emphasis on tectonic and paleogeographic controls. Acta Carsol 32-2:205-218 
Fetter CV (2001) Applied hydrogeology, 4th edn. Prentice-Hall Inc, New Jersey, USA

Günay G (2006) Hydrology and hydrogeology of Sakaryabaşı karstik springs, Çifteler, Turkey. Environ Geol 51:229-240

Günay G, and Bayarı CS (1989) Isotope survey of western taurids karst region, HU IAEA Research Contract RB 5019, Progress Report 1, p 30 (unpublished)

Gunn J (2007) Contributory area definition for groundwater source protection and hazard mitigation in carbonate aquifers. Natural and Anthropogenic Hazards in Karst Areas: Recognition, Analysis, and Mitigation. Geol Soc Lond 279:97-109

Katz BG, DeHan RS, Hirten JJ, Catches JS (1997) Interactions between ground water and surface water in the Suwanee River Basin, Florida. J Amer Water Res Assoc 33:1237-1254

Kresic N (1997) Hydrogeology and groundwater modeling. CRC Press, $\mathrm{p} 480$

Kurttaş T (1997) Environmental isotope investigation of gökova (Muğla) karst sources $\mathrm{PhD}$ Thesis, Hacettepe University, Institute of Science and Technology (unpublished), p 220

Land L, Huff GF (2009) Multi-tracer investigation of groundwater residence time in a karstic aquifer: Bitter Lakes National Wildlife Refuge, New Mexico, USA. Hydrogeol J 18:455-472

Mazor E (1991) Applied chemical and isotopic groundwater hydrology. Open University Press, Ballmoor, p 274

Musgrove M, Stern LA, Banner JL (2010) Springwater geochemistry at Honey Creek State Natural Area, central Texas: Implications for surface water and groundwater interaction in a karst aquifer. J Hydrol 388(1-2):144
Palmer AN (2010) Understanding the hydrology of karst. Geol Croat 63:143-148

Surinaidu L, Rao VG, Rao NS, Srinu S (2014) Hydrogeological and groundwater modeling studies to estimate the groundwater inflows into the coal Mines at different mine development stages using MODFLOW, Andhra Pradesh, India. Water Resour Ind 7-8:49-65

Tezcan L (2002) New isotopes and their uses in hydrological studies, 1. Symposium on the use of isotope techniques in national hydrology, Adana

Truesdell AH, Hulston JR (1980) Isotopic evidence of geothermal systems, Chapter 5. In: Fritz P, Fontes J-CH (eds) Handbook of environmental geochemistry: The terrestrial environment, A. Volume 2. Elsevier, Amsterdam, pp 179-226

Ünlü K, Şengör SS, Girgin S, Balta T (2004) Numerical modeling of water, an example of an environmental impact assessment (EIA) application. Symposium on Groundwater, Konya, p 23

Voss CI (2011) Editor's message: Groundwater modeling fantasiespart 1, adrift in the details. Hydrogeol J 19:1281-1284

White WB (2002) Karst hydrology: recent developments and open questions. Eng Geol 65:85-105

Yildırım N, Güner İN (2002) Isotopic and hydrogeochemical properties of waters in geothermal fields east of the büyük Nenderes graben, 1. Symposium on the use of isotope techniques in national hydrology, Adana 